\title{
Parents as parents-in-law in the light of Erik Erikson's theory
}

\begin{abstract}
The role of parents-in-law according to Erik Erikson's theory, has been analyzed in this paper.

Erikson claims that a man develops throughout his whole life, solving subsequently appearing crises. The proper solution of these crises enables the achievement of integration. The results of research, carried out by Menelaos Apostolou, regarding the influence of parents on the choice of a son or daughter-in-law have been presented in this paper. These results show that the marital choices of offspring most often lack their parents' approval, and they often also lead parents to use manipulation techniques. Such regularity is often the basis of difficult spouse-parent-in-law relationships.

The role of parents-in-law takes place in the period of middle adulthood in which an individual faces the productivity-stagnation process. It has been assumed that the role of parents-in-law is embedded in this crisis. According to Erikson, the crisis in the period of middle adulthood, as well as in any other period, is the friction of two opposing pursuits: progression and regression, where in case of middle adulthood, the progression stage is called productivity and regression - stagnation. Moreover, social and individual factors (including biological and psychological levels) activating regressive and progressive states in parents-in-law have been submitted for analysis.

It is stressed, in this paper, that the parents' virtue, which is care, is not limited only and exclusively to their own biological offspring - the process of upbringing should also include a broad understanding of the notion of providing welfare to future generations.
\end{abstract}

\section{Keywords}

Parents-in-law, Erik Erikson, family roles, developmental stage, upbringing.

In literature, there is little known research about the relationship between a married couple and their parents-in-law. Considering the substantial importance of this relationship, with regards to the functioning of a family unit, this paper will endeavor to provide the relevant discourse on the subject. 
Erik Erikson's theory has been assumed as alifecycle, since it is one of the many known concepts of the development of human being's mental health. Erikson says that a human develops throughout the whole life and consequently solves emerging crises. The proper solution to these crises enables the achievement of mental integration'.

The beginning of the role as parents-in-law usually starts in the period of middle adulthood, for which the 'productivity and stagnation crisis' is characteristic. It has been assumed that the realization of the roles of parentsin-law is inserted in this crisis. The aim of this paper is to discuss this process.

\section{The characteristics of developmental stages according to Erikson}

Erikson distinguishes between eight developmental periods in a man's life, where the last three occur in adulthood. Each new period commences when individuals become aware that they have a newly given task to perform, which they must overcome and resolve. The crisis arises when there is friction between two opposing pursuits: the progressive and regressive. The former is characterized by the pursuit to expand beyond $I$ - the desire of life. Whereas the latter is characterized by the pursuit of self-destruction: the excessive concentration on oneself.

The appropriate resolution of the crisis takes place when new mental functions are formed, enabling further development. But a lack of constructive solutions to a problem weakens an individual's ego ${ }^{2}$. 'Developing ego, in Erikson's concept, is autonomous in comparison to $i d$, it expresses an individual's sub-conscious, the individual style of experience synthesis defining $I$ identity, the ability to overcome conflicts, and to act in the world'3.

Erikson specifies eight developmental stages where each stage has a particular crisis:

1. Basic Trust vs. Basic Mistrust (oral-sensory, birth -2 years) - the most fundamental stage of life, where the major developmental task is to

\footnotetext{
E. Erikson, Childhood and Society, New York 1985, W. W. Norton \& Company.

E. Erikson, Childhood and Society, New York 1985, W. W. Norton \& Company.

A. Brzezińska, Modele i strategie zmiany rozwojowej, w: J. Strelau (ed.), Psychologia. Podręcznik akademicki, Gdańsk 2006, Gdańskie Wydawnictwo Psychologiczne, p. 239-283.
} 
learn whether or not other people (especially a mother) regularly satisfy basic needs;

2. Autonomy vs. Shame and Doubt (muscular-anal, 2-4 years old) - in this stage children are still very dependent on their parents, whose patience and encouragement help to develop a sense of autonomy; children also develop their first interests and master toilet training;

3. Initiative vs. Guilt (preschool, 3-6 years) - in this stage children develop courage, independence and learn to take initiative; children become frustrated for not being able to achieve their goals; a lot depends on the parents' attitude: if parents support children's efforts, they develop initiative-independence; if parents discourage children from mastering the world, they develop guilt;

4. Industry vs. Inferiority (latency, 6-12 years) - in this stage children learn to be responsible and diligent; if parents don't praise them for the accomplishments, they develop feelings of inferiority about their capabilities;

5. Identity vs. Role Confusion (adolescence, 13-19 years) - this stage is a kind of transition between childhood and adulthood, a special synthesis of earlier stages and anticipation of the future; adolescents must explore in order to form their own identity; parents' lack of or overabundance of support may lead to identity confusion;

6. Intimacy vs. Isolation (young adulthood, 20-35 years) - the first stage of adulthood; young adults try to successfully form love relationships with other people (marriage, family); failure in forming lasting relationships results in isolation and loneliness;

7. Generativity vs. Stagnation (middle adulthood, 35-65 years) - in this stage people try to build their lives, focusing on career and family; they want to contribute to the world by being active in their home and family; those who fail to accomplish this develop feelings of stagnation;

8. Ego Integrity vs. Despair (late adulthood, 65-death) - in this stage people look back on their lives and contemplate their accomplishments; if they see that they have led a productive and satisfying life they develop feelings of integrity; otherwise, they develop feelings of despair ${ }^{4}$. 
Erikson's theory is called the psychosocial theory of human beings mental development. As Calvin Hall and Gardner Lindzey, the authors of 'Theories of Personality', emphasise: 'It is important for a reader to remember what 'psychosocial' means, when it is used in regards to development. It means in particular, that a man's stages of life from birth to death are shaped by social influences entering into interaction with a mentally and physically growing up organism" 5 . The said argument corresponds to mental developmental theories, e.g. with Robert Havighurst's theory. In this theory, it is assumed that a given developmental task is the result of three factors - cultural effects, somatic changes and an individual's values and aspirations ${ }^{6}$. It shall also be pointed out that the adoption of the role of parents-in-law, as well as other developmental tasks, is subject to social and individual influences (on both a biological and mental level). These influences shall be discussed further in the paper.

\section{A parents' influence on the family life of grown up children in the selected research}

As previously mentioned, in literature there is little known research on married couples' and their relationships with parents-in-law. However, research on the influence of parents regarding the choices of an offspring's marriage can be found. Menelaos Apostolou is a researcher who systematically analyses this issue.

Apostolou, in many of his works, points out that the choices of an offspring's marriage are often not approved of by parents, thus becoming a source of conflict within a given family. As an example, parents, in comparison to their children, take a more qualitative approach and appreciate more the good deeds and the background of a future son or daughter-in-law ${ }^{7}$. On the other hand, young people take a more aesthetic approach appreciate the outer beauty more and appreciate a more interesting personality in a future spouse. Additional research

\footnotetext{
5 C. Hall, G. Lindzey, Teorie osobowości, Warszawa 1998, Wydawnictwo Naukowe PWN, p. 88.

6 R. Havighurst, Research on the developmental task concept, "The School Review" 5 (1956), p. 215-223.

7 M. Apostolou, Parent-offspring conflict over mating. The case of beauty, "Evolutionary Psychology" 6 (2008), p. 303-315.
} 
by Apostolou shows that parents, first of all, value health, good character and the similarity of practiced religion in future sons or daughters-in-law ${ }^{8}$.

It is worth pointing out that parental attitudes towards the matrimonial choices of their offspring is, to a certain degree, justified - parents, due to age, are very experienced and realize which features, in the long term, are important to the success of any marriage ${ }^{9}$. However, when helping adult children in choosing their spouse, the most important thing to bear in mind is their welfare.

Apostolou stresses, many times, that in the past, parents had much greater influence on the marital choices of offspring. This influence is still dominant in some societies.

"In pre-industrial societies, parents were able to control their children's decisions directly and to impose on them their in-law choices (Broud and Green, Stephens, 1963). Parents were able to do so because they could apply physical force on their children, and because their children, at marital age, were dependent on parental investment (Apostolou, 2010). These parental advantages are lost, however, in post-industrial societies where the rule of law and the protection of individual rights prevent parents from applying physical force on their sons and daughters. Furthermore, in post-industrial societies, marriage usually takes place at an age when children are financially independent. As a consequence, parents can no longer impose direct control over their sons' and daughters' mate choices, and instead resort to manipulation in order to influence mate choice indirectly"10.

Some of Apostolou's latest research focuses on the identification of a structure and the prevalence of manipulative tactics that parents employ to influence their children's mating behavior. Parents were to evaluate how often they apply the following manipulation tactics: "playing hardball" (examples: asking relatives/friends to lie to your child about the boyfriend/girlfriend, asking advice how to break up his/her relationship, kicking your child out of the house when he or she does something you do not approve of, blackmailing your child to do something), "advice and support" (examples: giving her/ him advice about romantic relationship, telling him/her to take precautions),

\footnotetext{
8 M. Apostolou, Sexual selection under parental choice: The evolution of human mating behavior, Hove 2014, Psychology Press.

9 W. Juroszek, Wybór współmałżonka - aspekt zadaniowy, ewolucjonistyczny i planowy, „Kwartalnik Pedagogiczny” 1 (2015), in press.

10 M. Apostolou, I. Papageorgi, Parental Mate Choice Manipulation Tactics: Exploring Prevalence, Sex and Personality Effects, "Evolutionary Psychology" 12 (2014), p. 588-620.
} 
"emotional manipulation" (examples: crying when he or she does something you disapprove of; sulking at him or her when he or she does something you disapprove of), "playing matchmaker" - (examples: explaining to him how to discriminate between potential partners, telling him/her how to behave so as to be attractive to the opposite sex), "coercion" - (examples: threatening him/her with consequences), "the carrot and stick" (examples: giving him/her financial support, house, money when he/she marries someone you approve of), "the guilt trip" (examples: making him or her feel guilty for doing something, giving him or her examples of proper/improper behaviors and their consequences) ${ }^{11}$.

Consistent with the original hypothesis, parents reported that they were willing to employ more manipulation on their daughters than on their sons. Additionally, mothers indicated more willingness to employ manipulation on their children, and on their children's mates, than fathers ${ }^{12}$.

Another finding was that the parental age was negatively related to their willingness to use manipulation on their children and on their children's mates. Older parents were less interested in using manipulation to influence their children's mate choice ${ }^{13}$. This can be explained due to the inverse correlation between increasing age and diminishing physical attributes. Age is related to vitality, energy, the tendency to make an effort, and also the manipulation that comes with it.

It may be assumed that a similar regular finding - related to parental influence on the lives of their adult children decreasing together with age - concerns also a married couple's parent-in-law relationship. In other words, the older the parents are, the less strength they have to influence the lives of their adult children and their children's spouses. It is worth noting that this influence may be both positive (understood as help and support) and negative (excessive interference and manipulation). Younger parents-in-law, in comparison to their elders, due to the fact that they are mentally and physically fit, may provide more help to a young married couple (e.g. by raising children). However, older parents-in-law may as well interfere more in their children's lives.

11 Can these be ibid or shortened together with fn 12-13 also M. Apostolou, I. Papageorgi, Parental Mate Choice Manipulation Tactics: Exploring Prevalence, Sex and Personality Effects, "Evolutionary Psychology" 12 (2014), p. 588-620.

12 M. Apostolou, I. Papageorgi, Parental Mate Choice Manipulation Tactics: Exploring Prevalence, Sex and Personality Effects, "Evolutionary Psychology" 12 (2014), p. 588-620.

13 M. Apostolou, I. Papageorgi, Parental Mate Choice Manipulation Tactics: Exploring Prevalence, Sex and Personality Effects, "Evolutionary Psychology" 12 (2014), p. 588-620. 
The initial period of marriage is difficult since young married couples have not as yet developed effective examples of communication. This often results in a high degree of intensityin their conflicts ${ }^{14}$. For example, the research conducted by Barbara Harwas-Napierała shows that a young married couple, in comparison to retired couples and those who are middle-aged, experience conflicts more frequently. It turns out that within this period - the initial period of marriage - parents-in-law should bear in mind the utmost sensitivity of this period and do everything so as not to increase the frequency nor the intensity of disputes between spouses. A hypothesis can be formulated (which in the future should be subjected to empirical verification) that such an attitude is characteristic of deeply religious parents (or parents-in-law). These parents may be recognized among others, as they include the sacramental dimension of marriage. The sacramental aspect of marriage assumes its non-separation. That is why deeply believing parents try to avoid disagreements between themselves and that of a married couple as they know it increases the risk of divorce. They try to give their support, as well as their prayer.

\section{Developmental crisis accompanying the role of parents-in-law}

Parental duty is, among others, to raise a child to the point where he or she can start their own loving family. This statement may seem trivial, but its overtone shall be completely different when we consider the fact that starting a family means finding a spouse. And a spouse of an adult child is a son or daughter-in-law to that child's parents.

The relationship of a son or daughter-in-law with their parents-in-law is based on the social contract of marriage, not on blood ties. In this sense, these people start off as strangers. In extreme situations (e.g. serious illness), it is probably confirmed more than once, that individuals related to each other by blood ties, have stronger relationships than people related only by marriage. The situation of a difficult labor of a daughter-in-law serves as a good example as the attention of her parents-in-law is more focused on their future grandchild's health or life, and not on the daughter-in-law's health or life. It does not need to be added, that the reaction of a mother to her laboring daughter is different

14 B. Harwas-Napierała, Komunikacja interpersonalna w rodzinie, Poznań 2008, Wydawnictwo UAM, p. 67. 
- in her case, where the health or life of both her laboring child and the childto-be's lives are both endangered.

An unfamiliarity must also be felt by the very parents-in-law whose attitudes, as suggested by research on divorcing couples, are often perceived by a son or daughter-in-law in the categories of punishment and manipulation ${ }^{15}$. Parentsin-law, probably, also very rarely receive gratitude for assistance provided with regards to grandchildren. The presented prerequisites are the basis to state that the role of parents-in-law is one of the most difficult positions within a family structure and constitutes a crisis situation for older spouses.

In this paper, the crisis accompanying the role of parent-in-law has been examined in relation to Erikson's theory. As mentioned earlier, in this theory it is assumed that a man develops throughout his whole life, where at every stage of life, there is a given crisis. It is the mutual friction of opposite aims: both progression and regression, where for the middle adulthood stage, progression is called productivity and regression deemed stagnation.

All these pursuits, which are related to the development and desire to expand beyond the $I$, are progressive in character. During middle adulthood, these are the actions related to the willingness to have offspring and raise them with a complete sense of parental responsibility. Regression, at this stage, is expressed by the obsessive need for pseudo intimacy and the temporal mutual repugnance of partners towards each other.

As mentioned earlier, the process of adopting the role of parent-in-law (which is the friction between progressive and regressive action) is subjected to individual and social influences (with the consideration of biological and mental levels).

The exemplary factor of biological nature, the ever changing psychosocial situations of older spouses may be illness, where the acceptance of decreasing physical strength is a challenge for people at the final stage of late adulthood. Illness usually increases dependence on others, in this case - adult offspring. Offspring usually set out assistance schedules for parents in agreement with their spouses, which may cause, in the event of an illness, ageing parents to be more heavily dependent on their sons or daughters-in-law. Such a situation may be a crisis experience, and at the same time may increase regression: anger,

15 H. Przybyła-Basista, Mediacje rodzinne w konflikcie rozwodowym. Gotowość i opór matżonków a efektywność procesu mediacji, Katowice 2006, Wydawnictwo Uniwersytetu Śląskiego. 
withdrawal, the accusation of others and oneself, and the feeling of injustice and frustration. Finally, there is despair and helplessness.

However, illness may also activate progressive stages. Decreasing strength often opens an individual to religious experiences - returning to God as the one who never forgets about anybody, even the weakest of the weak.

Social factors intensifying regressive stages are greatly reflected in Western culture. Family ties are not valued within this culture. Family is often reduced to two generations: parents and their small and later adolescent children. The moment they become independent there is a drastic loosening of intergenerational ties.

As an example, research by Ewelina Maciantowicz, that many young people (high school pupils, students) despite their visible fondness and warmth towards grandparents are at the same time resistant to contact with their elders ${ }^{16}$. Krystyna Ferenz, on the grounds of research conducted within selected MA theses, states that in seniors' opinions, emerging generations (fully active in their professional ranks) have a relatively low appreciation for family values ${ }^{17}$. It is worth emphasizing that such attitudes from the younger generation does not make it easier for those from the older generation to fulfill their developmental tasks. As only one party is orientated towards cooperation, this process is very difficult to be realized.

The low appreciation for family in a given society is a social factor generating regression states. In Western cultures, the meaning of family as an elementary social unit is increasingly being questioned. The results of such an attitude have their consequences within each of the eight previously mentioned stages of an individual's psychosocial development, including in this productivitystagnation period. Such a low value given to thefamily is not good for the development of virtue, which as described by Erikson, is the care for family and in particular for the elderly. All the same, in line with the theory of learning, young people would undertake a caring behavior towards their own parents, if they (young people) at an early stage of development had the opportunity to witness this such role being performed by their own parents as caretakers for the elderly. This mechanism, in psychology, is called modeling. Additionally, in line with the terms of causative conditioning, to acquire a certain behavior

16 E. Maciantowicz, Poglady wspótczesnej młodzieży na starzenie się i starość, in: S. Steuden, M. Marczuk (eds.), Starzenie się a satysfakcja z życia, Lublin 2006, Wydawnictwo KUL, p. 29-38.

17 K. Ferenz, Znaczenie rodziny w życiu człowieka z perspektywy osób starszych, in: A. Ładyżyński (ed.), Rodzina we współczesności, Wrocław 2009, Oficyna Wydawnicza ATUT, p. 97-106. 
(including this connected with the taking care of the elderly within a family), the consequences of this behavior is important to the so called reinforcements. If a child were rewarded for taking care of a grandparent, or punished for his or her lack there of, it would be learned that such an attitude would be considered a duty. And if a child did not experience such influences, they would not feel obliged to help the elderly, particularly their parents-in-law. It should be noted that for a son or daughter in-law, an ageing parent of their spouse is a stranger to whom there are no blood ties. That is why help for ageing spouses may be particularly difficult for sons or daughters-in-law.

Towards one's own parents, there is a greater chance to activate empathy. This element, of psychological nature, is one of the personality features which differentiates attitudes towards the taking care of the elderly. Individuals who are characterized with a relatively high sense of empathy, in comparison to a person of a low level of empathy, probably has a higher propensity towards a more caring attitude regarding their elder parents and parents-in-law as it is easier for them to empathize with their needs.

Mutual matrimonial love between the parents-in-law alone is a factor for simplifying the adoption of the role of parent-in-law ${ }^{18}$. The stronger that love is, the easier it is for those spouses to fulfill their developmental tasks, including the adoption of the role of parents-in-law. For example, the satisfaction of one's own marriage reduces the possibly to blame their adult children nor their sons and daughters-in-law for the excessive pursuit of independence, making it easier to draw borders along family lines and their fulfillment ${ }^{19}$. For a happy spouse, the other spouse is the most important person and reference point to the remaining relations within the family. The situation is exactly the opposite in the case of spouses, unhappy with their respective marriages, who relatively often experience states of regression: reluctance and even sometimes antipathy towards their spouse.

Other factors which activate states of progression for parents-in-law (and at the same time simplify the adoption of this role) are the following: spouses' religiousness (a large amount of research confirming that faith contributes

18 W. Juroszek, Relacje matzonków z matka i teściową wświetle teorii niezależności-wspólzależności $J a$, ,Kwartalnik Naukowy Fides et Ratio” 18 (2014), p. 64-73.

19 W. Juroszek, Autoprezentacyjne uwarunkowania relacji synowa-teściowa ze szczególnym uwzględnieniem ingracjacji, „Wychowanie na co Dzień” 12 (2013), p. 33-39. 
to fuller living through marriage) ${ }^{20}$, financial independence (simplifying the autonomy in decision-making), outside parenthood sources of building identity (the acceptance of a given marriage of an adult child is easier for those parents who also have other non-family interests and duties), having more children (generating a greater support net after children leave home, giving the sense of freedom in decision-making - e.g. parents are not dependant on visits from one child and their spouse).

According to Erikson, virtue is the undertaking to care for future generations, requiring one to work on oneself. In daily life, it shall be the so-called 'work on one's character'. Erikson, despite his psychoanalytical background, in his theory, allocates consciousness a special place - he states that the actions of an adult undertaken to solve developmental conflict rely largely on the extent of consciousness.

It may be assumed that for parents-in-law, such work on oneself may seem extremely difficult. They often shoulder a huge burden when helping young ones, yet their attitude is often perceived as manipulation. It shall be stressed here, that in Erikson's theory there is a kind of psychological guideline for parents-in-law on how to cope with such an extremely frustrating role - the role of parents-in-law. A parents-in-law's duty is to raise younger generations and pass on to them family values. Erikson stresses that this process is the source of progressive states. Raising younger generations activates altruistic processes which oppose egocentrism. However, Erikson notes that care for elderly parents should not be limited exclusively to their own biological offspring. In the process of upbringing it is important to include a widely understood notion of providing welfare to future generations.

Such attitudes exceed the typical care for offspring which is reduced to daily duties. It shall not be confused with the egoistic dependence of children (and grandchildren) on oneself and other progressive actions - bribery and excessive spoiling. All these actions, which are based on competition to gain 'a place in a child's heart' are also of a regressive nature. For example, the dependence of, a grandson on oneself is often the result of fear of the future, where a grandchild must be the one who one day will take care of his grandparents.

Care for future generations requires the attitude of gratitude, and yet being satisfied with the achievements of younger generations (children and

20 M. Braun-Gałkowska, Psychologiczna analiza systemów rodzinnych osób zadowolonych i niezadowolonych z matżeństwa, Lublin 1992, Towarzystwo Naukowe KUL. 
grandchildren) without their unnecessary comparison to the achievements of other children (friends or the rest of the family). In line with the theory of social comparisons, people compete for importance within their spheres of life with other representatives from their own group (reference group). Such comparisons, made too frequently, are the source of frustration, jealousy and discontent. Therefore, they are of a regressive nature as they concentrate their attention excessively on oneself, which impedes the expansion beyond $I$.

In conclusion, it is worth noting that the role of parents-in-law, which constitutes a developmental task, appears in a certain stage of life in the form of a crisis which should be solved. In the case of a period of middle adulthood, the role of parents-in-law is such a crisis. What is more, unsolved crises will probably appear in the next developmental period (occurring in old age) and will impede the resolution of crises typical for it: ego-despair-integrity. At the same time, the achievement of life wisdom as the result of a positive balance of life will be impeded. It should be empirically verified, how many unresolved problems with adult children and their spouses, commencing in the period of middle adulthood, will contribute to the increase of regressive states as parentsin-law in the period of old age.

\section{Bibliography}

Apostolou M., Sexual selection under parental choice: The evolution of human mating behavior, Hove 2014, Psychology Press.

Apostolou M., Papageorgi I., Parental Mate Choice Manipulation Tactics: Exploring Prevalence, Sex and Personality Effects, "Evolutionary Psychology" 12 (2014), p. 588-620.

Apostolou M., Parent-offspring conflict over mating. The case of beauty, "Evolutionary Psychology" 6 (2008), p. 303-315.

H. Bee, D. Boyd, The Developing Child, Boston 2009, MA: Pearson.

Braun-Gałkowska M., Psychologiczna analiza systemów rodzinnych osób zadowolonych i niezadowolonych z matżeństwa, Lublin 1992, Towarzystwo Naukowe KUL.

Brzezińska A., Modele i strategie zmiany rozwojowej, in: J. Strelau (ed.), Psychologia. Podręcznik akademicki, Gdańsk 2006, Gdańskie Wydawnictwo Psychologiczne, p. 239-283.

Erikson E., Childhood and Society, New York, 1985, W. W. Norton \& Company.

Ferenz K., Znaczenie rodziny w życiu człowieka z perspektywy osób starszych, in: A. Ładyżyński

(ed.), Rodzina we współczesności, Wrocław 2009, Oficyna Wydawnicza ATUT, p. 97-106.

Hall C., Lindzey G., Teorie osobowości, Warszawa 1998, Wydawnictwo Naukowe PWN.

Harwas-Napierała B., Komunikacja interpersonalna w rodzinie, Poznań 2008, Wydawnictwo UAM. 
Havighurst R., Research on the developmental task concept, "The School Review" 5 (1956), p. 215-223.

Juroszek W., Autoprezentacyjne uwarunkowania relacji synowa-teściowa ze szczególnym uwzględnieniem ingracjacji, "Wychowanie na co Dzień" 12 (2013), p. 33-39.

Juroszek W., Relacje małżonków z matką i teściowa w świetle teorii niezależności-wspólzależności $J a$, "Kwartalnik Naukowy Fides et Ratio" 18 (2014), p. 64-73.

Juroszek W., Wybór wspótmałżonka - aspekt zadaniowy, ewolucjonistyczny i planowy, "Kwartalnik Pedagogiczny" 1 (2015), in press.

Maciantowicz E., Poglądy współczesnej młodzieży na starzenie się i starość, in: S. Steuden, M. Marczuk (eds.), Starzenie się a satysfakcja z życia, Lublin 2006, Wydawnictwo KUL, p. 29-38.

Przybyła-Basista H., Mediacje rodzinne w konflikcie rozwodowym. Gotowość i opór matżonków a efektywność procesu mediacji, Katowice 2006, Wydawnictwo Uniwersytetu Śląskiego.

Szczukiewicz P., Rozwój psychospołeczny a tożsamość, Lublin 1998, Wydawnictwo Uniwersytetu Marii Curie-Skłodowskiej. 